\title{
The Struggle to Preserve Iowa's State Banking System, 1920-1933
}

\section{Calvin W. Coquillette}

"It is as if the manufacturers of old oaken buckets had gotten laws passed to prohibit the establishment of municipal water systems."

UNLIKE THE BANKING SYSTEM of any other developed country, the U.S. banking system was (and is) composed of two systems: one is made up of national banks, chartered and examined by the Office of the Comptroller of the Currency, in which all banks are required to be members of the Federal Reserve System; the other exists in each state wherein banks are chartered by a state bank superintendent. State-chartered banks may elect to join the Federal Reserve System, but in the 1920s and the early years of the Great Depression, most did not. Statechartered banks and bankers associations struggled to preserve their state banking systems at a time when the two most divisive issues in the history of twentieth-century American banking converged: the permissibility of interstate branch banking and the federal guarantee of bank deposits. A study of Iowa's banking conditions during the 1920s and early 1930s suggests why most bankers fought so hard to resist branch banking and the federal deposit guarantee.

The characteristic feature of the American banking system was the predominance of separately owned, independently

1. J. G. Curtis, "The Turning Financial Worm," The Nation, 23 April 1930, 489.

THE ANNALS OF IOWA 59 (Winter 2001). (C) The State Historical Society of Iowa, 2001. 
chartered unit banks, which could be either state or national banks. Such banks had no branches, no bank affiliates, and no corporate headquarters located elsewhere. The state-chartered unit bank was the linchpin of the nation's banking system, aided by two powerful allies in every state: the state bankers association and the state superintendent of banking. The Iowa Bankers Association (IBA) represented 99 percent of all Iowa banks in 1920, state and national alike, and the Iowa Superintendent of Banking, a state government official, was responsible for 1,346 state-chartered banks with deposits of $\$ 658$ million. Including its national banks, deposits in Iowa exceeded $\$ 1$ billion in 1920, a total not to be equaled again until $1940{ }^{2}$

As Iowa led the nation in bank failures from 1921 through 1931, with an average of 87 per year, its state banking system came under attack. ${ }^{3}$ The nub of the controversy over Iowa's excessive rate of bank failures was whether the state's banking system or agricultural deflation was more to blame. At the national level, reformers proposed such reforms as eliminating the longstanding prohibition against branch banking and instituting a federal deposit guarantee.

Iowa bankers vigorously opposed such reforms and, at the annual conventions of the IBA, reinforced the sanctity of the independent unit bank and the state banking system. One speaker objected that critics charged bank failures up as "a crime against the unit bank." If it was suggested that the small bank "might have outlived some of its usefulness," Iowa bankers asked where else the "character loan"-a loan without capital or collateral-could be obtained $?^{4}$ If federal reform of the nation's dual banking system was proposed, it could only come over the howls of protest from state bank superintendents, state bankers associations, and thousands of country bankers in Iowa and across the country. Far too many citizens (and voters) con-

2. See Report of the Superintendent of Banking for the Year Ending June 30, 1920 (Des Moines, 1920), 7-8; and Annual Report of the Comptroller of the Currency, 1920 (Washington, DC, 1921), 126-28.

3. Federal Reserve Bulletin 23 (September 1937), 868; The Internal Debts of the United States, ed. Evans Clark (New York, 1933), 332.

4. Proceedings of the Forty-Fourth Annual Convention of the Iowa Bankers Association (Des Moines, 1930), 271-75 (hereafter cited as IBA Proceedings and year). 
sidered their farm community, their local bank, and their state banking system to be inviolate.

THE PROBLEM OF BANK FAILURES predated the Great Depression in the upper Midwest. Bank failures in the farm states reflected the dropping commodity prices of crops and livestock. Corn and hogs were especially hard hit. Iowa's dependence on corn and hogs meant that lowa farmers and farm banks were more exposed to the severe farm price deflation that began in the 1920s.

Price deflation and farm failures, combined with the problem of farm mortgage debt, proved to be especially burdensome for Iowa farmers, bankers, and other lenders. By 1925, total U.S. farm mortgage debt was $\$ 9.4$ billion; Iowa's total was $\$ 1.4$ billion, or 15 percent of the nation's total. By 1930, only five states other than Iowa-Illinois, Wisconsin, Minnesota, Nebraska, and Texas-had farm mortgage debt in excess of $\$ 500$ million, and none of those states had even half of Iowa's amount. ${ }^{5}$ Because farm mortgage debt totaled about 70 percent of total farm indebtedness, and because double the dollar amount of Iowa farmland was mortgaged compared to the next highest states, Iowa farmers carried much higher debt burdens than farmers elsewhere.

Banking conditions in Iowa and the upper Midwest reflected the agricultural crisis of the 1920s. While total U.S. bank deposits increased by 40 percent from 1922 to 1930 , the banks in the upper Midwest experienced a deposit decline of 6 percent. $^{6}$ Total Iowa bank deposits declined during that period by 8.5 percent. Deposits in state-chartered Iowa banks declined even more, from $\$ 658$ million to $\$ 563$ million, or 14 percent, while the

5. U.S. Department of Agriculture, Yearbook of Agriculture, 1932 (Washington, DC, 1932), table 480, p. 912. Commercial banks nationwide held a total of only about $\$ 1$ billion (10.8\% of the total) of farm mortgage loans, while life insurance companies $(22.9 \%)$, Federal Land Banks (12.1\%), mortgage companies $(10.4 \%)$, and retired farmers held the rest. Ibid., 3 .

6. Des Moines Register, 10 February 1930; Northwestern Bancorporation Review, First Quarter 1930. States reported in the upper Midwest region were Michigan, Wisconsin, Minnesota, Iowa, Nebraska, and North and South Dakota; also included, for purposes of this survey, were Montana, Wyoming, Idaho, and Washington. 
number of state-chartered banks dropped by almost $300 .^{7}$ The top five states with the most bank failures in the 1920s were, in rank order: Iowa, North Dakota, Minnesota, South Dakota, and Nebraska. Although banks in these five states accounted for only slightly more than 6 percent of total bank deposits, they contained 24 percent of all banks in the United States. Most of the failed banks were small state-chartered banks that served small farm communities with populations of less than 2,500. A Federal Reserve Board study noted that "one town in Iowa with a population of 1,300 had four banks in 1920 . . . one county in North Dakota with a population of 10,000 had 16 banks. $^{\prime 8}$

By mid-1930 the president of the Iowa Bankers Association noted that, in spite of the stock market crash the previous October, lowa farms and farm banks had been through the worst. "Probably no state in the Union," he said, "has suffered more at the hands of national psychology or from national observation than this state, whose name has been dragged about in a most wanton fashion." ${ }^{\prime 9}$ Yet in the fourth quarter of 1930 the nationwide bank failure rate accelerated dramatically. Increased bank failures in Iowa reflected the further decline in key farm prices. The price per bushel of corn was 92 cents in September, fell to 55 cents in December, and declined steadily thereafter for the next 30 months. Hogs were $\$ 9.45$ per hundredweight in late November, but dropped $\$ 2.50$ by the end of the year. In the fourth quarter of 1930, bank deposits nationwide declined by $\$ 915$ million (4.7\%), and hundreds of banks failed, only to set the stage for 1931, when more than two thousand failed. As the public became more fearful of banks, people began to hoard currency, and currency in circulation declined by about $\$ 800$ million. $^{10}$

7. Many more than 300 state-chartered banks failed during that time, but many were reborn or chartered anew under new names and new ownership.

8. Report of the Superintendent of Banking for the Year Ending June 30, 1931 (Des Moines, 1931), 26; Internal Debts of the United States, 332; Federal Reserve Board, "Summary Report of the Federal Reserve Committee on Branch, Chain, and Group Banking," 12 November 1932, Presidential Subject Files (hereafter cited as PSF) "Federal Reserve," box 155, Herbert Hoover Presidential Library, West Branch, Iowa (hereafter cited as HHPL).

9. IBA Proceedings, 1930, 205.

10. Charles P. Kindleberger, The World in Depression, 1929-1939 (Berkeley, CA, 1975), 38; Banking and Monetary Statistics (Washington, DC, 1943), 283; Milton 
BECAUSE none of the five states with the most bank failures in the 1920s permitted any form of branch banking, contemporary critics (and subsequent historians) suggested that the number of unit bank failures might have been significantly reduced had branch banking been permitted for all banks prior to $1920 .{ }^{11}$ But small unit bankers in Iowa, fearing that interstate branch banking would allow big banks to compete directly in any unit bank's trade area, perceived branch banking to be the most immediate threat to their state banking system, and they fought to preserve unit banks as the backbone of that system. ${ }^{12}$ In short, proponents of branch banking proclaimed it to be the panacea for reducing or eliminating bank failures. Small unit banks, in contrast, feared a concentration of banking resources in a handful of giant interstate banks. While the argument raged from 1921 to 1931 , a total of 9,355 banks failed nationwide.

The branch banking controversy was not new to the industry. Annual conventions of the American Bankers Association (ABA) periodically resolved to oppose branch banking in cities, counties, or states. A speaker at the 1922 ABA convention portrayed branch banking as monopolistic and oppressive; it threatened American banking "freedom" and was nothing less than a "ca-

Friedman and Anna Jacobson Schwarz, A Monetary History of the United States, 1867-1960 (Princeton, NJ, 1963), 478. A total of 564 banks failed in November and December 1930; 2,213 failed in 1931.

11. See Eugene Nelson White, The Regulation and Reform of the American Banking System, 1900-1929 (Princeton, NJ, 1983), 221. White argues that branch banking would have "reduced the number of banks and facilitated banks' mutual assistance in times of crisis." Independent unit banks feared a reduction in their numbers through branch banking, especially if branching were to occur across state lines. Branch banking would have been a more viable expansion alternative in 1900-1929 than in the early years of the Great Depression, when branch banking networks contracted. Permitting branch banking after 1930 would have had little or no effect in a time of deposit deflation, currency hoarding, mounting loan losses, and "red ink."

12. Branch banking was not uniformly opposed by all state banks. In states where statewide branching was permitted, state banks led the way because national banks were prohibited to branch until 1927. That prohibition stemmed from the original National Bank Act of 1863. Section 6 stated that persons forming a national bank association had to specify the place where its "operation of discount and deposit are to be carried on"; and Section 8 provided that its usual business shall be transacted "in the place specified in the organization certificate" (emphases added). 
lamity. ${ }^{\prime \prime 3}$ Legislators found such rhetoric persuasive. National banks were prohibited from establishing full-service branches until 1927. In 1930 only nine states permitted unlimited statewide branch banking, while 22 prohibited it outright. The remainder either restricted branches to the county, city, town, or village in which the main bank was located (10 states) or had no legislation regarding branch banking (7 states). ${ }^{14}$ When proponents of branch banking argued that national banks in states that allowed branching should at least be allowed to establish branches in the city where they were established, the ABA resolved that all forms of branch banking should be regarded as "detrimental to the people of the United States. ${ }^{\prime 15}$ Iowa bankers had long believed that branch banking would be detrimental to their state banking system; in the spring of 1921, the Iowa legislature, bowing to pressure from the IBA, had voted almost unanimously to prohibit any form of branch banking within the state.

During the $1920 \mathrm{~s}$, many national banks in states that permitted branch banking surrendered their federal charters in favor of state charters in order to establish branches. Regulators of national banks feared an erosion of their authority and lobbied for passage of the McFadden Act. When it passed in 1927, national banks were permitted to establish full-service branches in their home-office cities if state banks were permitted to do so. But in Iowa, as in $\mathbf{2 2}$ other states, the prohibition against most forms of branch banking meant that national banks were restricted just as its state banks were. ${ }^{16}$

The McFadden Act could be seen as a victory for unit banks in the anti-branching states because branch banks were still effectively precluded in those states. This troubled the Federal Reserve staff, who objected that national banking laws were "adjusted to standards set by various states." ${ }^{17}$ Iowa bankers

13. Wilbert M. Schneider, The American Bankers Association: Its Past and Present (Washington, DC, 1956), 210-11.

14. See "Summary of State Laws Relating to Branch Banking," Federal Reserve Bulletin, April 1930.

15. Schneider, American Bankers Association, 210-11.

16. "Summary of State Laws Relating to Branch Banking," 258.

17. Federal Reserve Board, "Summary Report on Branch, Chain, and Group Banking," quotes on pp. 24, 59. 
preferred to mold their own destiny apart from the federal government or Federal Reserve System. State bank legislation was designed to preserve and enhance the Iowa state banking system and not risk encroachment from federal authorities or banks in other states.

When the U.S. House Banking Committee opened hearings on branch banking in 1930, Iowa bankers became concerned. The U.S. Comptroller of the Currency, John Pole, whose office regulated and examined all national banks, was troubled by three recent developments. First, the McFadden Act of 1927 had not settled the branch bank question. National banks continued to desert in favor of state bank charters. Second, bank failures nationwide since 1920 had cost $\$ 1.7$ billion in total deposits (\$201 million from Iowa banks). ${ }^{18}$ Third, the development of "group banking" was perceived by some observers to be a way to circumvent anti-branching laws. ("Three years ago, unnoticed and unremarked," Pole exclaimed, "today it controls onefifth of the nation's banking resources! "19 $^{\prime 9}$ )

In response to a survey on group banking in Iowa, IBA Secretary Frank Warner noted that in January 1929 the Northwestern National Bank of Minneapolis had organized a bank holding company (known as "Banco") that owned the stock of the Minneapolis bank. By year-end it had acquired the stock of 105 banks in eight states representing $\$ 470$ million in total assets. The corporation (later "Norwest" and now "Wells Fargo") acquired Iowa's largest bank in Des Moines as well as two banks in Mason City, one in Sioux City, and one in Denison. Its primary competitor, the First National Bank of Minneapolis, had formed the First Bank Stock Corporation and reported 85 bank affiliates in 7 states with $\$ 433$ million in total assets. ${ }^{20}$

18. Harris Pett, Manager of Research and Statistics, Federal Reserve Bank of Chicago, speech, June 1930, in IBA Proceedings, 1930, 154.

19. John W. Pole, Comptroller of the Currency, statement to U.S. Senate Subcommittee of the Committee on Banking and Currency, Hearings on the National and Federal Reserve Banking Systems, 71st. Cong., 3d sess., 1930, 57.

20. Frank Warner to Gurden Edwards, secretary, Economic Policy Commission, American Bankers Association, 29 August 1929, "Northwest Bancorporation," box 232, Iowa Bankers Association Archives, Special Collections, Parks Library, Iowa State University, Ames, Iowa (hereafter cited as IBA); E. W. Decker, president, Northwestern Bancorporation, to Stockholders, 26 February 1930, 
Warner speculated that certain group banks or their officers might attempt to gain control of the IBA; or that Iowa independent unit banks would spin off into a separate association and thus fragment the Iowa banking system; or that group banking would become a backdoor entry to branch banking as affiliates converted to branches of the lead banks when the law permitted. George Susens of the Minnesota Bankers Association admitted that some small independent banks felt that the MBA was dominated by the Minneapolis banks. But "most of our country bankers think that nothing will stop group banking or even branch banking. ${ }^{21}$

Branch banking, whatever its form, inevitably became entangled with the problem of bank failures. Most failed banks were small, independent state banks in farm communities, supported by their state bankers associations and state banking departments. Almost two-thirds were banks with capital of $\$ 25,000$ or less. A Federal Reserve study concluded that "a direct and unmistakable relationship exists between the size of banks, their earning power and mortality rate. ${ }^{\prime 22}$ One critic compared the unit bank and its supporters to a manufacturer of "old oaken buckets" determined to prevent the development of municipal water systems. $^{23}$

Independent unit bankers resented such criticism. They argued that excessive bank failures did not call for abandonment of unit banks or the instigation of interstate branch banking. Bank failures, they insisted, were due to farm conditions. The remedy, therefore, was to stabilize agriculture, not reform the state banking systems.

"Banco," box 235, IBA; Charles S. Popple, Development of Two Bank Groups in the Central Northwest (Cambridge, MA, 1944), 195-98.

21. Frank Warner to W. C. McFadden, George Starring, Wall G. Coapman, and George Susens, 20 November 1929, "Central States Conference," box 227, IBA; George Susens to Frank Warner, 22 November 1929, ibid.

22. Of all state-chartered banks in Iowa with less than $\$ 1$ million in assets (about 500 banks), over one-third had earned less than 3 percent on capital .from 1926 through 1930; and of banks with less than $\$ 250,000$ in assets (about 325 banks), over half had earned less. Federal Reserve Board "Summary Report on Branch, Chain, and Group Banking," 32 (quote above from p. 7).

23. Curtis, "The Turning Financial Worm," 489. 
Proponents of branch banking, on the other hand, tended to represent urban banks and care little about agriculture. They pointed to the banking system in Canada, where there was a grand total of ten banks: one had two branches and the other nine had 140 to 880 branches each. There, bank failures had been minimal compared to the United States. Certainly, replied the opponents of branching, and look at Canada and the Canadian economy: vast tracts of undeveloped wasteland, a glut of depressed wheat stocks, and a banking cartel with no competition. There was no place for the "character" loan in conservative Canadian banking and no place for traditional American autonomy and individuality. Unlike Canada, about 70 percent of Iowa bank stockholders resided in the bank's hometown. Local citizens had a vested interest in the local bank's survival and prosperity. ${ }^{24}$ At year-end 1931, proponents of branch banking and defenders of unit banking remained divided.

MEANWHILE, President Herbert Hoover had become convinced, as he told the nation on radio, that "the battlefront today is against the hoarding of currency."${ }^{\prime 25}$ Bank failures had resulted in increased hoarding of money in backyards and under mattresses and finally forced Hoover's hand. In September 1931 he had learned that the amount of hoarded currency was a "rocksolid" $\$ 800$ million and growing at the projected rate of $\$ 250$ million per week. ${ }^{26}$ The amount and rate of hoarding could be correlated to the numbers and frequency of bank failures, and the problem intensified. While Hoover believed that the bank failure rate might be checked through loans to marginal banks from the Reconstruction Finance Corporation (RFC), which he

24. Susan Estabrook Kennedy, The Banking Crisis of 1933 (Lexington, KY, 1973), 207; Annual Report of the Comptroller of the Currency, 1920 (Washington, DC, 1920), 62-67. See also John M. Chapman and Ray B. Westerfield, Branch Banking: Its Historical and Theoretical Position in America and Abroad (New York, 1942), 144.

25. Herbert Hoover, "Radio Address on the Hoarding of Currency," 6 March 1932, Public Papers of the Presidents of the United States-Herbert Hoover-January 1, 1932 to March 4, 1933 (Washington, DC, 1977), 94.

26. Meyer to Hoover, 8 September 1931, PSF "Federal Reserve Correspondence 1931," box 159, HHPL; Goldenweiser to Meyer, 14 September 1931, ibid.; Mills to Hoover, 1 October 1931, PSF "Financial Matters-Banking and Bankruptcy Correspondence 1931," box 155, HHPL. 
proposed a few months later, he also believed that currency hoarding provided an opportunity to organize and mobilize a citizens' army to promote patriotism and economic nationalism. ${ }^{27}$

The Hoover campaign against hoarding began in February 1932 with a well-publicized White House conference. The conference became a virtual declaration of war against the estimated $\$ 1.5$ billion being hoarded. General Charles Dawes, head of the new RFC, proclaimed that because "millions of people [hoarders] are slowly committing economic suicide," it was now necessary to "reach out and create mass movement in this war." Julius Barnes, president of the National Chamber of Commerce, wanted assurance "that money deposited in the bank carries some measure of safety." Harry Haas, president of the ABA, suggested that the banks' role in the campaign against hoarding might be awkward. "If the banks should start such a program," he explained, "then the public would say they have a selfish motive because they want to get the deposits. ${ }^{128}$

Hoover took the campaign against hoarding to heart. He appointed Colonel Frank Knox, publisher of the Chicago Daily News, to head the campaign and "to reawaken a new spirit in a nation which is now vastly discouraged. ${ }^{\prime 29}$ At Hoover's urging and within one week, Knox had selected a chairman for each state and had produced six "very striking" full-page ads that he expected some 400 newspapers to run as a public service. ${ }^{30} \mathrm{He}$ selected Colonel Charles Burton Robbins, former assistant secretary of war and president of the Cedar Rapids Life Insurance Company, to chair the campaign's "Iowa Department." Robbins enlisted "Minute Men," including many Iowa bankers, who signed pledge cards available in banks and post offices. Minute

27. On the relationship between hoarding and bank failures, see Elmus Wicker, The Banking Panics of the Great Depression (New York, 1996), 70-71. On Hoover's attitudes toward loans to marginal banks, see Calvin W. Coquillette, "A Failure or 'A Very Great Public Service'? Herbert Hoover, Iowa Banks, and the National Credit Corporation," Annals of Iowa 58 (1999), 388-412.

28. "Conference of February 6, 1932, at the White House," PSF "Hoarding," Hoarding Conference, box 173, HHPL, 10-13, 17-20.

29. Ibid., 30-31; Telegram, Hoover to Knox, 11 February 1932, PSF "Hoarding," Correspondence, box 173, HHPL.

30. Telegram, Knox to Hoover, 16 February 1932, ibid. 
Men (and women, also known as "Minute Men") pledged to "place the general welfare of IOWA first, to talk constructively, to work zealously to restore confidence, and to execute any orders given to me by my superior officers. ${ }^{\text {"31 }}$ Some 25,000 Iowans enlisted as Minute Men. Their mission was to rebuild confidence and restore momentum to the local economy.

The national campaign also included a special Treasury bond issue to be offered to hoarders who feared banks. IBA Secretary Warner lamented the "disadvantages that banks would be in if the contemplated bonds were sold in a house-to-house canvass." He spoke for most Iowa banks when he said that "the [bond] campaign might result in the loss of their deposits, and this campaign would be just one more thing to make it difficult for the small rural bank to survive." The Chicago Tribune agreed that "the bonds may draw as much from deposits in banks as from hiding places in the home." Sale of the bonds never materialized in quantity. The IBA advised its member banks to "not take too aggressive a part. ${ }^{\prime 32}$

The campaign against hoarding had only limited success. Colonel Knox estimated that $\$ 201$ million had been redeposited in banks by March $26 .^{33}$ But deposits in all U.S. banks for the first six months of 1932 declined from $\$ 45.8$ billion to $\$ 42$ billion, or 8.3 percent. In Iowa the decline was even more severe at 17 percent. While national bank deposits in Iowa declined by 14 percent, deposits in state-chartered banks, representing more than eight out of ten rural banks, declined by 19 percent. Deposits in state-chartered banks in all other states declined by only 7.7 percent. $^{34}$ In large part the legacy of the anti-hoarding campaign was continued depression and the federal guarantee of bank deposits that came about in 1933.

31. "Citizens Reconstruction Organization (Iowa Department)," "Hoarding," box 261, IBA.

32. Frank Warner to Harry Haas, 2 March 1932, "Hoarding," box 261, IBA; Chicago Tribune, 9 March 1932; IBA Proceedings, 1932, 356.

33. Knox to Hoover, 29 March 1932, PSF "Hoarding," Correspondence, box 173, HHPL.

34. Federal Reserve Bulletin (October 1932), 664-66; Annual Report of the Comptroller of the Currency (Washington, DC, 1933), 319-23; Report of the Superintendent of Banking for the Year Ending June 30, 1933 (Des Moines, 1933), 17-18. 
THE PRIMARY BARRIER to the success of the anti-hoarding campaign was that depositors had no assurance of safety in banks. Someone suggested that the federal government should promote its own safe alternative for those who feared banksthe Postal Savings System. Postal savings accounts, which paid 2 percent interest, were available in every post office; deposits, which were guaranteed by the federal government, were restricted to $\$ 2,500$ per account. Bankers had fought against their instigation in 1916 and remained opposed to them in 1932. Knowing that bankers would vehemently object to the suggestion, Hoover quickly pointed out why the anti-hoarding campaign should not endorse postal savings accounts.

I can illustrate . . by recounting the experience of a town in Texas where there was a run on one bank out of the four. The postmaster wanted to be helpful, and stated that if anyone was not satisfied with the safety of his deposits he could bring his money to the post office, since there the United States government guaranteed the deposit. Within three hours, every bank in the town was closed and the post office had all their cash resources. I have felt, therefore, that the most dangerous thing we could say to the whole country is that they should take their money and put it in the postal savings bank, because they will take deposits from the present banks, as well as their hoarded money.

Hoover acknowledged that the federal government guaranteed the deposits, but he believed, rightly, that the strategy of encouraging postal savings would have jeopardized the Federal Reserve and state banking systems.

Iowa bankers agreed that postal savings accounts posed a threat to the state's banking system. While the number of statechartered banks in Iowa declined from 893 in June 1931 to 703 in June 1932 and total state-chartered bank deposits declined by $\$ 117$ million, deposits in the Postal Savings System more than doubled nationwide from $\$ 346$ million to $\$ 783$ million. Postal savings deposits in Iowa totaled \$23.6 million in June 1932 and

35. "White House Hoarding Conference," 28. Even without promotion, deposits in the U.S. Postal Savings System, which had averaged about 5 percent annual growth from 1927 to 1929, suddenly increased by 25 percent in 1930 . Friedman and Schwarz, Monetary History of the U.S., 497. 
represented a higher percentage of total bank deposits than in any other state. The per capita deposit average was $\$ 9.51$, double the national average of $\$ 4.72$. Keokuk banker Bill Logan referred to "many smaller towns in Iowa where Postal Savings deposits exceed the bank deposits by many times." ${ }^{136}$

The ABA fought hard against congressional initiatives to raise the permissible per account balance for Postal Savings deposits from $\$ 2,500$ to $\$ 10,000$ and to permit checking privileges. Bill Logan applauded the ABA's success. He believed that postal savings was nothing more than federal branch banking. ${ }^{37}$ Postal savings, as Hoover admitted, was a two-edged sword that combined federal branch banking and a federal deposit guarantee.

INITIAL FEDERAL LEGISLATIVE EFFORTS aimed at banking reform sought to extend the federal deposit guarantee to national, but not state-chartered banks. It had long been suggested that "the National Banking System should be buttressed against times of stress by means of a Deposit-Guarantee Reserve." Such a reserve would stand as a "GUARANTEE of every dollar deposited in each and every national bank throughout the country" and immunize them from failure. ${ }^{38}$ Depositors in state-chartered banks, however, would not be similarly protected. Further, the proposal would have outraged state bankers associations, whose members were mostly state banks. Frank Warner, secretary of the IBA, believed that there was another way to both ensure depositor confidence in banks and circumvent a deposit guarantee. Warner could embrace federal intervention only if the autonomy of the Iowa state and national banking systems could be preserved.

36. Report of the Superintendent of Banking for the Year Ending June 30, 1931 (Des Moines, 1931), 18; Report of the Superintendent of Banking for the Year Ending June 30, 1932 (Des Moines, 1932), 16; Friedman and Schwarz, Monetary History of the U.S., 712-13; Annual Report of the Comptroller of the Currency, 1932, 78-79, 84-85; IBA Proceedings, 1932, 211.

37. IBA Proceedings, 1932, 210-11.

38. Orange Belt News (Sacramento, CA), 28 November 1930. See other related materials and clippings in PSF "Financial Matters-Banking and Bankruptcy Correspondence," box 155, HHPL. 
He pointed out to Iowa Congressman C. W. Ramseyer, a member of the House Ways and Means Committee, that "bank failures result from loss of public confidence, often generated by a foolish or malicious word spoken on the street. ${ }^{\prime 39}$ The IBA had lobbied the Iowa legislature in 1929 to pass a "false rumors against banks" bill to protect its state-chartered banks. In December 1930 a similar bill was pending before Congress. ${ }^{40}$ Idle gossip or slanderous remarks could then be punishable by federal law. Such legislation was intended to deter bank panics, enforce confidence, and put a halt to bank runs. Congressman Ramseyer would have none of it. Such legislation, he thought, was the responsibility of each state, not the federal government. Warner countered his objections by citing the example of a minister ("of all people who would become embittered against a bank charged by law to protect the depositors"), who was turned down on a small loan at a bank in northeast Iowa, took a train to Minnesota, and mailed 20 anonymous typewritten letters to merchants in the Iowa town claiming that the bank was unsafe. On the day the letters arrived, depositors withdrew about $\$ 10,000$ from the town's banks. ${ }^{41}$ Warner believed that if individual bank panics could be checked, Iowa bank failures would be reduced or eliminated. Moreover, perhaps such legislation would continue to deter consideration of branch banking and the deposit guarantee, both of which the IBA opposed.

Individual states had long tried to initiate deposit guarantees, beginning in 1829 when Governor Martin Van Buren of New York had introduced the New York Safety Fund for banks. Between 1831 and 1858, five other states, including Iowa in the latter year, adopted insurance plans. All of those plans had been abandoned by 1866 . The establishment of national banks in 1863 forced the conversion of most state banks to national bank charters. State bank insurance, of course, did not apply to national banks. The plans folded. ${ }^{42}$ Depositors were left unprotected.

39. Warner to Ramseyer, 27 December 1930, "False Rumors" file, box 251, IBA. 40. Helen M. Burns, The American Banking Community and New Deal Banking Reforms, 1933-1935 (Westport, CT, 1971), 11.

41. Warner to Ramseyer, 3 January 1931, "False Rumors" file, box 251, IBA.

42. Carter H. Golembe, "The Deposit Insurance Legislation of 1933: An Examination of Its Antecedents and Purposes," Political Science Quarterly 75 (1960), 181-92. 
Between 1907 and 1920, eight western states approved deposit insurance for state banks. The plans periodically assessed state banks in order to provide a state fund to pay depositors of failed banks. By 1932 all of the state insurance plans had become insolvent or inoperative because of the number of bank failures. ${ }^{43}$

Concurrently, between 1886 and 1933 Congress considered some 150 separate legislative proposals for federal deposit insurance. In early 1932, at least 21 separate deposit insurance bills were referred to the House Banking Committee, and in May the U.S. House of Representatives finally passed one of them. Representative Harry Steagall of Alabama, chair of the House Banking and Currency Committee, gave his name to the bill, which called for a "Federal Guaranty Fund" for bank depositors that would have cost Iowa banks more than $\$ 300,000$. $^{44}$

The ABA and state bankers associations vigorously opposed the Steagall Bill, arguing that good banks would be taxed to pay for the bad, that banking skill would be taxed to pay for incompetence, and that knowledge of banking would be made to pay for the mistakes of ignorance. The IBA Legislative Committee reported that "while the bill has passed the House, there is little likelihood of it being given further consideration by the Senate." Aside from its cost, the IBA opposed the Steagall Bill because of the "disastrous results that occurred in the eight states that enacted similar legislation for their state banks"; because the bill would have required state-chartered Iowa banks to join the Federal Reserve System, where membership and requirements "may be changed by others living away and apart from the State of Iowa"; because Iowa's hundreds of local banks could not possibly benefit "from a plan outside of the State" and in which "Iowa banks incorporated under Iowa State Laws could never hope to have a voice"; and because a federal guarantee of bank deposits would undermine the autonomy of Iowa's state banking system. ${ }^{45}$ Thanks to the opposition of Senator Carter Glass (D-VA),

43. Eugene Nelson White, "State-Sponsored Insurance of Bank Deposits in the United States, 1907-1929," Journal of Economic History 41 (1981), 537-57.

44. IBA Proceedings, 1932, 276-77.

45. Thomas B. Paton, General Counsel, American Bankers Association, Federal Guaranty Fund for Bank Depositors, 1932, "Steagall Bill," box 261, IBA; IBA Proceedings, 1932, 276-77, 307; IBA Legislative Committee, IBA Tax Committee, 
an acknowledged "father" of the Federal Reserve System-reinforced by President Hoover, the Treasury Department, the Federal Reserve Banks, and the New York money-center banks that abhorred the idea of bailing out failed farm banks in the South and West-the bill was not about to move.

Senator Glass had his own agenda for bank reform in 1932. His bill would have permitted a national bank not only unlimited branches within its home city, but statewide and even in adjacent states up to 50 miles from its headquarters. Warner and the IBA Legislative Committee were outraged. In a scathing memorandum to Iowa's two senators and eleven House representatives, he railed that "if this bill is passed, deference to state sovereignty has been eliminated." He fervently hoped that no one wished to see "'octopus' banking in your home state that may throttle the very existence of the hundreds of independent Iowa banks. ${ }^{146}$ Clearly, the IBA perceived the "octopus" of intra- and interstate branch banking as a huge threat to the state's banking system.

The banking catastrophes of 1931 that provoked the Glass and Steagall Bills in 1932 marked a turning point in the focus of the IBA. The focus was no longer on Iowa legislation for Iowa banks; rather, the IBA was forced to consider pending federal legislation that threatened lowa's state banking system. If that legislation were to pass, Warner foresaw that federally chartered banks would gain a competitive advantage over state-chartered banks when it came to branching. Likewise, state-chartered banks would also be disadvantaged if only Federal Reserve System member banks were eligible for the federal deposit guarantee. ${ }^{47}$

As state banking systems came under increasing attack, the IBA resisted federal proposals that would have undermined the state banking system. Some IBA members believed that the Federal Reserve envisioned a unified banking system that would eliminate state banks. At the same time, banks also faced the threat of "the pernicious guaranty bill." ${ }^{\prime 48}$ Perhaps, some pro-

and Ivan O. Hasbrouck, president, Iowa Bankers Association, "Memorandum to Iowa Congressional Delegation," "Glass Bill," box 294, IBA (underscoring in original).

46. "Memorandum to Iowa Congressional Delegation."

47. IBA Proceedings, 1932, 339-40.

48. Northwestern Bancorporation Review, 20 July 1932. 
posed, some compromise on branch banking might remove the heat generated by bank failures. John Pole, the U.S. Comptroller, highlighting the dilemma between the federal deposit guarantee and expanded branch banking, told the House Banking Committee that he favored "a system of branch banking built up around strong city banks operating under close government supervision." While he could not deny that the Steagall Bill would provide greater safety to the depositor, he could not accept a federal government guarantee of some $\$ 40$ billion in bank deposits. He concluded that "a general [federal] guaranty of bank deposits is the very antithesis of branch banking." ${ }^{\prime 49}$

By mid-year 1932, Congress and Hoover administration officials, like the nation's bankers, were gridlocked on expanded branch banking and the federal deposit guarantee. President Hoover unequivocally opposed the guarantee and had misgivings about expanded branch banking. He knew that most of the nation's bankers and state bankers associations were vehemently opposed to both. When Congress adjourned in July 1932, branch banking and the federal deposit guarantee were left unresolved.

When the lame-duck Congress returned in December, the fireworks began again. No fewer than 18 deposit insurance bills were introduced in the Senate. The Steagall Bill, which restricted the federal deposit guarantee to Federal Reserve member banks only, continued to attract the most serious attention. Its passage, argued Haynes McFadden, secretary of the Georgia Bankers Association, would mean "the wholesale slaughter of small [state-chartered] banks" as federally guaranteed banks "would siphon all of the deposits out of the non-guaranteed banks which would automatically perish." Anticipating that the Steagall Deposit Guarantee Bill would be combined with the Glass Branch Banking Bill, McFadden asked Frank Warner to send "three or four of your hardest hitters" to Washington to "belly up to your own Senators and Congressmen if the crisis occurs." ${ }^{\prime 50}$

49. John W. Pole, Comptroller of the Currency, statement to U.S. Senate Subcommittee of the Committee on Banking and Currency, Hearings on the $\mathrm{Na}$ tional and Federal Reserve Banking Systems, 71st. Cong., 3d sess., 1930, 7.

50. McFadden to Warner, 3 January 1933, and Warner to McFadden, 9 January 1933, "Deposit Guaranty Bill," box 294, IBA. 
Warner confirmed that an IBA committee would indeed be sent to Washington to lobby against the bills if necessary. He knew that his members, like McFadden's in Georgia, almost unanimously opposed the deposit guarantee. First, most IBA member banks were state-chartered and were not Federal Reserve members. Second, the proposed cost of deposit insurance -2 percent of deposits payable to a federal guaranty fund in order to be eligible - was staggering. Third, banks pointed to the failure of prior state bank insurance schemes, without exception. Yet if deposits in federally chartered banks were insured, what other choice would state-chartered banks have but to form their own state insurance fund in order to remair competitive $?^{51}$ Fourth, bankers resented using a federal mechanism to bail out their weaker brethren. Fifth, they were fearful of any legislative attempt to tie a federal deposit guarantee to the Glass provision that would allow Federal Reserve member banks to branch across state lines. Either way-federal guarantee or interstate branch banking-state-chartered banks would lose. Either way would jeopardize the role and existence of state banking systems, and Frank Warner of the IBA was not going to let it happen if he could help it.

ON JANUARY 19, 1933, federal legislation became secondary because of a small banking panic that triggered the failure of 26 Iowa banks in 24 hours. ${ }^{52}$ After Roosevelt had defeated Hoover in the November 1932 election, bank failures in Iowa had accelerated and farm prices had declined to their lowest level of the year ( 6 cents per bushel of corn at elevators in northwest Iowa). As Warner put it, "something heroic" needed to be done to contain depositor stampedes. ${ }^{53}$

With banks falling like dominoes, officers of the IBA and the State Banking Department hurriedly crafted a bill, rushed it

51. Warner awkwardly noted, "This brings us to the point that it might not be unlikely that it might be well to consider the setting up of a 'Guaranty of Deposits' system here in this state and submitting such a bill to the General Assembly when it meets next August, 1933." Warner to Fred Figge, 29 May 1933, ibid.

52. Des Moines Register, 22 January 1933.

53. IBA Proceedings, 1933, 247. 
through the Iowa House and Senate, and got it signed by the governor, all in six hours on January 20, 1933. The Iowa Bank Conservation Act established in law a practice that the IBA had instituted the previous July as a result of a ten-county banking panic. Voluntary "Depositor's Agreements" between a bank and depositors gave banks the option to restrict deposit withdrawals for a specific period. The goal was to buy time, avoid a bank receivership, and restore public confidence. The "trusteeship provision" in Depositor's Agreements had first been tried in November 1932. It was offered to depositors as an alternative to failure. Slow and frozen assets were removed from the bank and turned over to trustees, or conservators, "to be liquidated as, if, and when it would be in the best interests of depositors." The bank agreed to divert all earnings usually for three years, and depositors agreed that the trustees could limit withdrawals and deposit interest rates. ${ }^{54}$ When the Iowa Bank Conservation Act instituted the trusteeship provisions of the Depositor's Agreements into law, it salvaged state banking by permitting a state-chartered bank that otherwise would have failed to continue to function as a depository. Because the law had originated as Senate File 111, banks that were forced to use it became known as "one-eleven" banks.

Of a total of about 1,400 national and state-chartered banks in Iowa in 1925, 802 remained by mid-February 1933. About 10 percent operated as "one-eleven" banks, with 50 or so located in north central and northwest Iowa, where farm mortgage foreclosures provoked farmer militancy. ${ }^{55}$ The number of one-eleven banks would escalate dramatically despite the governor's call for a moratorium on farm foreclosures. In the wake of the Iowa law's success, Frank Warner was swamped with dozens of requests from other states for information about the law, which became an accepted alternative to bank closings, and he was

54. Ibid., 248.

55. Henry A. Wallace to E. A. Rumely, Committee for the Nation, 10 February 1933, Henry A. Wallace Papers, Special Collections, University of Iowa Libraries, lowa City; Rodney D. Karr, "Farmer Rebels in Plymouth County, lowa, 1932-1933," Annals of Iowa 47 (1985), 637-45; John Shover, Cornbelt Rebellion: The Farmers' Holiday Association (Urbana, IL, 1965), 41-57. 
pleased to see similar emergency legislation passed in Nebraska and Missouri. ${ }^{56}$

WARNER remained concerned about legislative initiatives in Washington, however, and he did what he could to stymie them. When the Glass Bill was introduced for the fourth time in early January 1933, the IBA supported Senator Huey Long's filibuster. The amendment to allow Federal Reserve member banks to branch across state lines drove Long into a frenzy. He held up all Senate legislation for three weeks, forestalling any possible action in the House. ${ }^{57}$ Due in part to Long's efforts, the Glass Bill as amended and passed allowed national bank branches only in states that permitted branching. The federal deposit guarantee never came up because Senator Glass would not hear of it. And Frank Warner was saved an emergency train trip to Washington.

In February 1933, when the banking situation deteriorated further, Congress passed a joint resolution that enabled national banks to take advantage of state legislation. The proviso was that "nothing shall permit the establishment of branch banks not allowed by existing [state] laws. ${ }^{158}$ The Iowa legislature had its salvage measure for state-chartered banks through the Iowa Bank Conservation Act. Now national banks in Iowa could shelter themselves under the act, become a "one-eleven" bank, and remain open. So, too, could threatened banks in states such as Nebraska and Missouri. Bank conservation legislation served to sustain state banking systems and preserve them from federal encroachment following the panic. Without such legislation, in Iowa anyway, most small farm banks would have been wiped out in the final days of the crisis. Given that eventuality —untold numbers of Iowa banks in receivership-they could

56. L. H. Earhart to C. A. Worthington, 6 February 1933, “Emergency Banking 1933," box 61, Federal Reserve Bank of Kansas City Archives, Kansas City.

57. Kennedy, The Banking Crisis of 1933, 72; Jordan A. Schwarz, The Interregnum of Despair: Hoover, Congress, and the Depression (Urbana, IL, 1970), 219-20.

58. Chester Morrill, secretary of Federal Reserve Board of Governors, to M. L. McClure, chairman and Federal Reserve Agent, Federal Reserve Bank of Kansas City, telegram, 27 February 1933, "Emergency Banking 1933," box 61, Federal Reserve Bank of Kansas City Archives. 
not have been resurrected to become part of the reopening of the banks later in March. ${ }^{59}$

In just three weeks between mid-February and President Roosevelt's bank closing proclamation on March 6, 1933, more than half of all Iowa banks became one-eleven banks. Had there been no one-eleven legislation, failed banks would have outnumbered surviving banks and severely impaired the state banking system. The Iowa Bank Superintendent insisted that his department was going to reorganize all of the one-eleven banks, and that every bank that opened better be sound, "because, my friends, we do not want to go through this experience ever again." By mid-1934 almost every one of the one-eleven banks had been released by their conservators. The IBA was proud to claim that "there are very few homes or farms that are as much as 30 minutes away from a bank."

The closing and opening of the banks by mid-March, followed by the unprecedented flurry of federal legislation, told Iowa bankers that Roosevelt's New Deal had assumed a life and momentum of its own. The Steagall Deposit Guarantee Bill had passed the House in 1932 by an overwhelming margin. The Glass Branch Banking Bill, despite the Long filibuster, had been rammed through the Senate in January. By April 1933 the Glass and Steagall Bills had been combined on the legislative calendar. All that remained was reconciliation of the branch banking and deposit guarantee issues.

Because the banking crisis had brought the new Congress into extraordinary session, and because Congress had dealt with omnibus legislation for industry, agriculture, and the un-

59. Elmus Wicker criticizes state legislation that "was drafted and passed at breakneck speed" and "allowed Governors and state banking officials to close all banks within a state, limit deposit withdrawals, or allow directors of individual banks to declare temporary moratoria and limit withdrawals." It was true that "each state reacted to protect its own interests without regard to its effect on others," and this, Wicker claims, was an important catalyst to triggering the nationwide "banking panic of 1933". in March. Wicker's study, unfortunately, focuses almost exclusively on Federal Reserve System actions, figures, and member banks, and ignores the majority of the nation's banksthose chartered by individual states. See Wicker, Banking Panics, 126-29, 144 $45,149$.

60. Ibid., 142; IBA Proceedings, 1934, 69. 
employed, bankers could not expect to go unscathed. Warner could not expect Iowa's five new representatives and one new senator to be passive, either, for as he noted, all had come from Iowa communities that knew of "no other banking condition except for their own, which was dismal. ${ }^{\prime 61}$

To state bankers and their associations, the great unknown was Roosevelt himself. The president probably could have had about anything he wanted when it came to banking, Carter Glass and Harry Steagall notwithstanding. Roosevelt, the public perceived, had "saved" the banks, calmed the public's anxieties, engineered the reopenings, and gotten the country moving positively once again. Warner thought that Roosevelt was "at least 'lukewarm' if not opposed to anything savoring of the guaranty of bank deposits or to any provision that would destroy the unit bank or interfere with state Banking within its own border." Warner knew that "such discussion touches upon very vital issues," depending on the form of the combined bill. ${ }^{62}$

The "very vital" issues boiled down to the survival of each state's banking system. Dependent on the system of statechartered banks in Iowa and every other state were, of course, the state bankers associations, state banking departments, trade journal publishers, advisory firms, and related suppliers. Statechartered banks would not be able to compete effectively, given the privileges pending for Federal Reserve member banks only. A reduction in their numbers, if not extinction, seemed inevitable.

Small banking interests shuddered when in May 1933 the Glass Bill, amended again, provided that no bank could obtain the deposit guarantee unless it was a Federal Reserve member. The Steagall Bill, also amended again, provided that all banks were eligible, but only with minimum capital of $\$ 50,000$. Iowa bankers saw the bills as a threat to the system of state banking, as "giants intended to slaughter the small rural bank and install some form of [branch] banking or federal unification removed from the 48 states. ${ }^{\prime 63}$

61. Warner to F. A. Arnold, 9 June 1933, "Glass-Steagall Bill," box 294, IBA.

62. IBA Proceedings, 1934, 214-15.

63. IBA Proceedings, 1933, 191. 
When Roosevelt signed the Glass-Steagall Bill, or "Banking Act of 1933," in June, the deposit guarantee of $\$ 2,500$ per account was, of course, incorporated-for all banks. The final legislation required that state-chartered banks join the Federal Reserve System within two years, but this was later eliminated. Second, the minimum capital requirement was reduced to $\$ 25,000$, although state banks were subject to examination by the new Federal Deposit Insurance Corporation. Federal Reserve member banks were prohibited from branching where state law prohibited state banks from doing so. From the perspective of Iowa bankers-and most of the nation's independent unit bankers-the above provisions were the only ones that made a strategic difference to the industry.

Roosevelt's Farm Relief Act, combined with revamping the federal credit system to create the new Farm Credit Administration, resulted in more money flowing to agriculture than at any time since World War I. Total deposits in Iowa banks increased by $\$ 60$ million in 1933-1934. Ironically, the federal deposit guarantee was undoubtedly the most important factor in ensuring the survival of small rural banks. Iowa alone in 1934 had 475 towns with a population of fewer than 1,000 served by a unit bank. ${ }^{64}$ It is inconceivable that all 475 banks could have survived the depression of the 1930s without the federal guarantee and without more than the few bank failures that were experienced after mid-1933.

The federal deposit guarantee was the single most important banking reform to emerge from the legacy of the Hoover administration and Roosevelt's first one hundred days of legislation. ${ }^{65}$ State-chartered bankers knew that the deposit guarantee had become entangled with branch banking. To permit only Federal

64. IBA Proceedings, 1934, 117.

65. See Friedman and Schwarz, Monetary History of the U.S., 434, who state that "federal insurance of bank deposits was the most important structural 'change to result from the 1933 panic, and, indeed in our view, the structural change most conducive to monetary stability since state bank notes were taxed out of existence immediately after the Civil War." Unlike the demise of state banks that resulted from their notes being "taxed out of existence," the deposit guarantee was intended to preserve both systems of banks-state-chartered banks and national banks-and the stability of bank deposits on which Federal Reserve System monetary policy is based. 
Reserve member banks to receive either the deposit guarantee or the right to expanded branch banking would have meant that state banks could not have been competitive. Once Congress approved the deposit guarantee for state banks, the legislation moved quickly.

Still, it was resisted by bankers of all stripes, including Iowa's state-chartered bankers. H. J. Stuhlmiller, cashier of the State Savings Bank of Fontanelle, wondered about the guarantee and whether, after a year of operation in 1934, enough was enough. He suggested to fellow Iowa bankers that Congress had "diagnosed the case of banking and told us we were sick." Perhaps a dose or two of FDIC insurance premiums was advisable- "but like all powerful drugs it lurks with danger, and I honestly fear the outcome unless we wake up from this lethargy and shake this off." ${ }^{\prime 66}$

Stuhlmiller anticipated the deposit insurance crisis of the 1980 s by about fifty years. His grandchildren would witness the virtual demise of the savings and loan industry and the preservation of both state and national banking systems. Federal limitations on both intrastate and interstate branch banking until 1997 ensured that state-chartered banks in the unit banking states could preserve their territorial monopolies except from local competition. If state-chartered banks in the unit banking states could survive, so, too, would state banking departments and state bankers associations.

FRANK WARNER and his fellow Iowa unit bank members fought to preserve the Iowa state banking system when both banks and the economy deteriorated rapidly. The state of Iowa epitomized the two sickest and most threatened industries in the United States from 1930 to 1933: banking and agriculture. The struggle to preserve both began early in the 1920s when the symptoms of their illness first became apparent. During the later years of the Hoover presidency, the Iowa state banking system teetered on collapse. By March 1933, it was essentially bankrupt. The chief results of desperate measures were the instigation of Depositors Agreements and bank trusteeships; the 
federal deposit guarantee that included state banks; the limitation on Federal Reserve member banks branching both intrastate and interstate; and the preservation of state banking systems. The wonder is that the Iowa banking system even survived the federal battles to win their struggle for state banking autonomy. 
Copyright of Annals of Iowa is the property of State of Iowa, by \& through the State Historical Society of Iowa and its content may not be copied or emailed to multiple sites or posted to a listserv without the copyright holder's express written permission. However, users may print, download, or email articles for individual use. 